\title{
GPR35 Gene
}

National Cancer Institute

\section{Source}

National Cancer Institute. GPR35 Gene. NCI Thesaurus. Code C131180.

This gene plays a role in kynurenic acid-dependent signaling. 